\title{
THE USE OF PRICE WATERFALL MODEL (PWM) IN LOGISTICS
}

\author{
Krzysztof Senczyna \\ Vendavo / Czestochowa University of Technolog, Poland
}

\begin{abstract}
The purpose of the work is to present the capabilities achievable by implementing the Price Waterfall model (PWm) for logistic enterprises. An Innovative Logistic Company (ILC) should, as far as possible, exploit the potential of information technologies delivering data for further processing. The data managed by a Logistic Information System may be used to streamline a pricing process in the sector of logistic services. The PWm was chosen because its linear structure coincides with the linear form of equations of logistic costs' structure. The transaction data processed by a Decision Support System (DSS) based on the PWm allows to make an optimum price decision in a negotiation process considering the parameters of the current price strategy.
\end{abstract}

Keywords: innovative logistics, pricing model, Price Waterfall Model, Pricing Process, Pocket Margin, Pricing Leakage

DOI: $10.17512 /$ znpcz.2016.1.18

\section{Innovative Logistic Company (ILC)}

The market of logistic services is a derivative of the market and of the economics of the environment, i.e. a dynamic environment of events in constant movement, full of new models of services and solutions in a constant effort to seek new optimisation and innovation solutions. Having a capacity, in such a variable environment, targeted at launching new solutions, is a prerequisite to be able to generate an added value for the client. This allows to make the client believe that cooperation with a given company is favourable for both parties and, most importantly, beneficial in a long-term perspective. This enables to create new innovative projects and enhance the existing solutions in the positive ambiance of a win - win strategy.

By referring to the materials from Logistyka 2008 conference (Pfohl 2008), such a significant added value for a client, allowing to improve one's position in negotiation processes, can be introduced for a client by developing and promoting innovativeness in logistics. Those ILCs having logistic systems and networks have the highest potential to apply and model such changes. A company's business indicators can be improved by implementing such changes, as confirmed by Pfohl in the work (Pfohl 2008), and EBIT may rise by several per cents. One should keep in mind obviously that such an implementation innovative process may not necessarily bring convincing outcomes in the initial phase. As in each project, common sense and patience are the best advisors. 
In particular, the studies undertaken by The Economist (Agent of change 2012, s. 30-33.) confirm the significance of implementing innovations. Managers in established world-class enterprises expressing their opinions in such surveys have identified the following factors as crucial new processes in the recent years:

- outsourcing

- digitalizing of the services - data streams

- virtualized office services

The far-fetched and considerable influence of IT solutions and of implementation of data processing technologies is therefore confirmed. It can be concluded when analysing the results of the surveys that the key directions can be defined for the following areas:

- business solutions e.g. outsourcing,

- hardware - electronics, M2M, RFID and many others (Sumorek 2014),

- information technologies, data flow and processing.

In the work [4], the term innovative logistics attaches special importance to one of significant areas, namely Integrated Information Systems. Depending on the company size, capital capacity and other economic and technical factors, gradation can be started here from the most expensive system such as ERP, SAP (aiding the most complex technical and logistic solutions (Szkoda 2013; 2015.)) to less complex systems accommodated to a given company and its turnover.

Integrated Information Systems create data streams which can be used in innovative projects in an ILC. Such an active approach to data stream management and full process control in logistic processes are the key attributes of companies having the ILC brand.

On the other hand, the deployment of new innovative projects in the area of data stream management may lead to undesired consequences for a company. The i2Nike fallout story, i.e. a case of $i 2$ system implementation at Nike, proves how hard and costly such phenomena can be. Nike has suffered losses of around USD 100 million due to the lack of full synchronisation and consistency between the integrator's companies and Nike (Bozarth, Handfield, 2007 s. 670-672; Murphy, Wood 2011). Chaos was seen in the company's business structure by deploying the i2 system, especially in the procurement and logistic area. The implementation process was probably not prepared correctly and tested. The implementation initially disrupted the flow of old documentation, but has not been replaced swiftly enough with new habits and personnel training. The overall project cost is estimated at USD 400 million, which to some extent made the client confident that the whole project will not slow down corporate logistics, but quite the opposite, should expedite the order lead time.

\section{Information technology in logistics}

Information technology in logistics has become a pre-condition for carrying out more and more complex tasks imposed by the changing market. It allows to deploy new concepts of system solutions becoming the inherent part of logistics 
(Gołembska 2010 p.167). IT systems play various roles in logistics, hence multiple new opportunities emerge formed by a stream of data describing the parameters of the phenomena occurring in logistic processes.

A chart in Fig. 1 shows a Computer Integrated Logistic System (CIL).

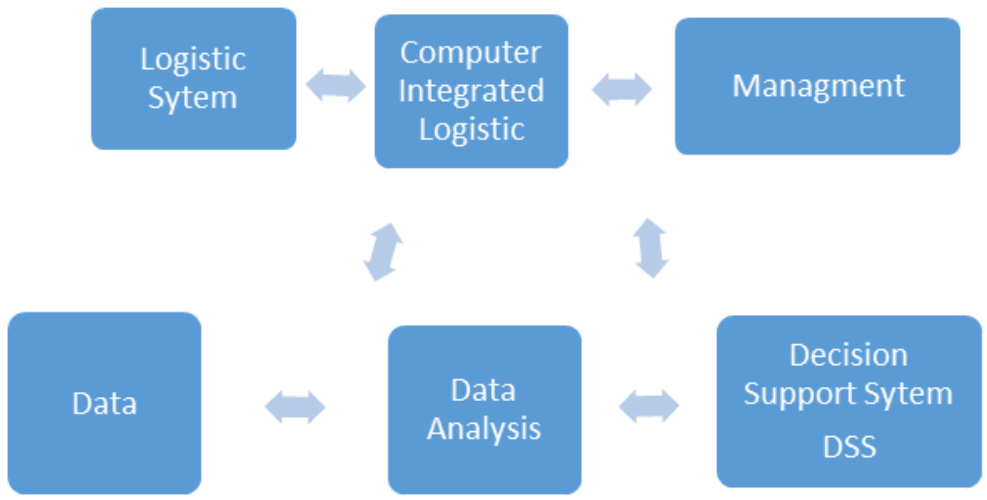

Figure 1. Computer Integrated Logistic system CIL

Source: Own work.

Data is a raw material in the system for many specialised applications and system. The Decision Support System is one of the subsystems. The data assembled in the DSS is analysed with various data models with view of streamlining the decision-making process. A product pricing process is one of the key processes essentially impacting a company's operations. If feasible, it should be subject to a separate decision-making process using the Data Subsystems, i.e. Data Collection, Assembly and Appraisal. Data analysis management

\section{Cost equation structure in logistics}

The following is the definition of basic equations in the domain of logistics Total Logistic Cost - TLC.

$$
T L C=K_{t}+K_{m}+K_{z}+K_{r}+K_{o}+K_{u}
$$

$\mathrm{K}_{\mathrm{t}}$ - transport costs

$\mathrm{K}_{\mathrm{m}}$ - warehousing (warehouse maintenance) costs,

$\mathrm{K}_{\mathrm{z}}$ - inventory storage costs,

$\mathrm{K}_{\mathrm{r}}$ - order execution costs,

$\mathrm{K}_{\mathrm{o}}$ - packaging costs,

$\mathrm{K}_{\mathrm{u}}$ - lost profit costs.

Particular components are summed up in the equation in order to calculate total logistic process costs. To calculate logistic costs, the indirect cost calculation method is proposed to be employed from the DPP (Gołembska 2010 p. 51) procedure where logistic costs are grouped into the following cost groups: 
- storage costs

- transport costs

- internal costs

Each of the points below creates a series of components, for instance DPC

(Direct Product Cost) is calculated after summing up:

- product unit acquisition costs

- product unit movement costs

- ordered product preparation costs

- product loading costs

- storage costs

- inventory costs

References provide that such analysis by sub-components enables to associate real logistic costs with a given product. A prerequisite for introducing a price model is to realistically estimate logistic costs associated with a given product, and such a price model furnishes current DPC (Gołembska 2010 p. 52) - logistic information during negotiations. An additive linear form in the cost method is indicative and points out that a price model in the field of logistic costs should be characterised by the structure equations' linearity, see also (Blaik 2010 p. 377).

\section{Pricing Power}

Warren Buffet said 'The single most important decision in evaluating a business is pricing power'.

Logistic companies concentrate the majority of their resources and energy to construct logistic chains correctly and optimally. It is the most natural direction of actions. By focussing fully on implementing their basic company activity, no due regard is given to the product pricing process, and most of all to the Pricing Policy (http://www.mckinsey.com/insights/marketing_sales/the_power_of_pricing) coordination process, i.e. an enterprise's price policy. Many publications concerning a price policy (Stiving 2011; Kocialski 2014) highlight in the beginning that it is quite a common phenomenon in the behaviour of companies from different industries. Such a phenomenon of 'underdeveloped pricing process' is a very serious shortcoming, though. The company's Pricing Power is being destroyed as a result.

In order to positively finalise the entire service provision process, i.e. to sell a logistic product, all the costs charged have to be covered and profit has to be achieved. Any deviations from such assumptions destroy a company' business foundations.

Current knowledge in the domain of Pricing Policy is a field of usable knowledge evolving dynamically in the recent years. It comprises a number of models estimating an attempt to answer such questions as:

- How can a company's financial result be changed by adjusting the Pricing Policy appropriately?

- If and how Pricing Policy assumptions can be realigned to utilise the market and company potential as effectively as possible? 
The market these days is usually a consumer-driven market. A client is the most sought "commodity", their choices and behaviours are determining the market situation. Pricing Policies emerge with a highly dynamic product price change process due to such consumer-oriented market patterns. An example of such a situation is a chart in Fig. 2. As seen, the most active Pricing Policy is run by Amazon, which is changing product price 9 times over 12 hours, while other suppliers once in 12 hours or leaving it as it is. A new problem arises from a client's point of view. How to choose an optimum time of placing an order when a product price is so variable over time. Possibly this type of a hyperactive Pricing Policy is a strategy developed based on client and market behaviours, but only Amazon has such knowledge. It is an example of a pricing strategy typical for B2C - Business to Customer market solutions.

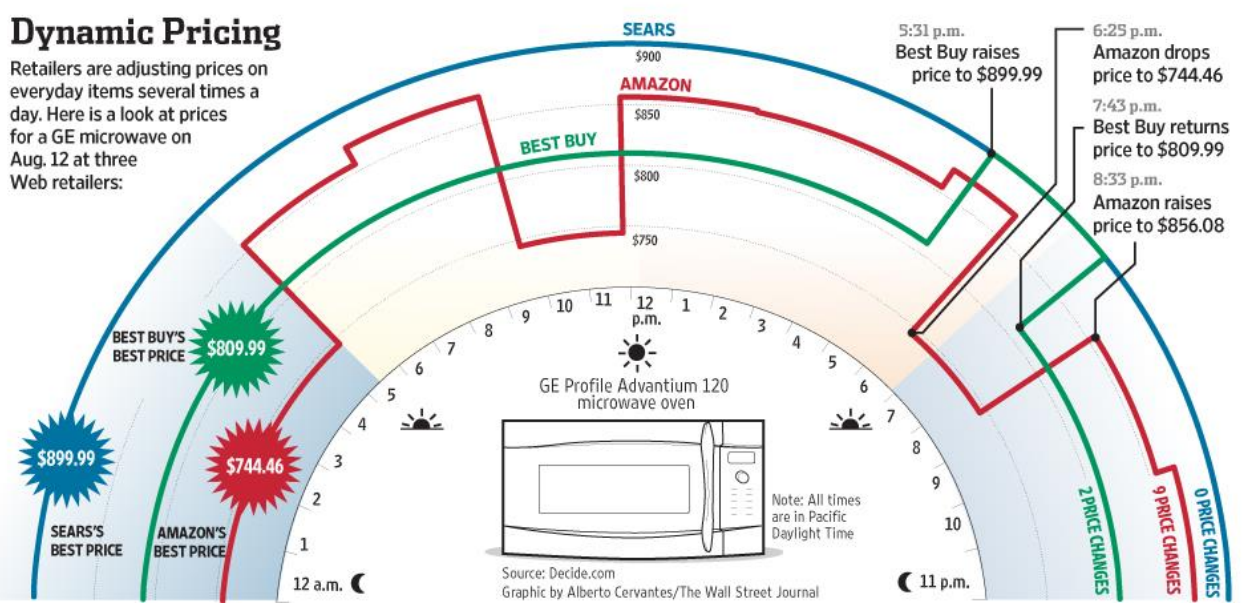

Figure 2. Product price adjustment patterns over $12 \mathrm{hrs}$ for 3 suppliers

Source: Own elaboration.

Successive, new solutions are being created in the price strategy database as proven by the term Visionary Pricing introduced in one of distinguished publications in the recent years (Smith 2012). The new concepts cropping up of market image and enterprise environment put increased pressure on capturing dynamic fluctuations in changes not only at the current moment, but also attempt to anticipate directions of changes in the future. Such tools as a pricing mode are required for a pricing policy model. A price of a company's given product, steered by the parameters of the Pricing Policy selected at the specific stage, is established directly with such a tool.

\section{The Price Waterfall model (PWm)}

Cost equations in a logistic process are simple linear dependencies as presented in item 3. This allows to formulate an assumption that a price model should be based on linear dependencies. A linear model is defined in the field of pricing models, whose 
structure is presented by a classical model referred to as the Price Waterfall model (PWm). Its graphical representation, so-called Mario chart, is in Fig. 2. The name adopted may be misleading with the term Waterfall (WF) often used in information technology. The WF (https://en.wikipedia.org/wiki/Waterfall_model) describes software development process management. This is a model of rather historical importance right now, which has been intensively replaced by an iterative stricture, socalled Agile model (Bereza 2014 s.27).

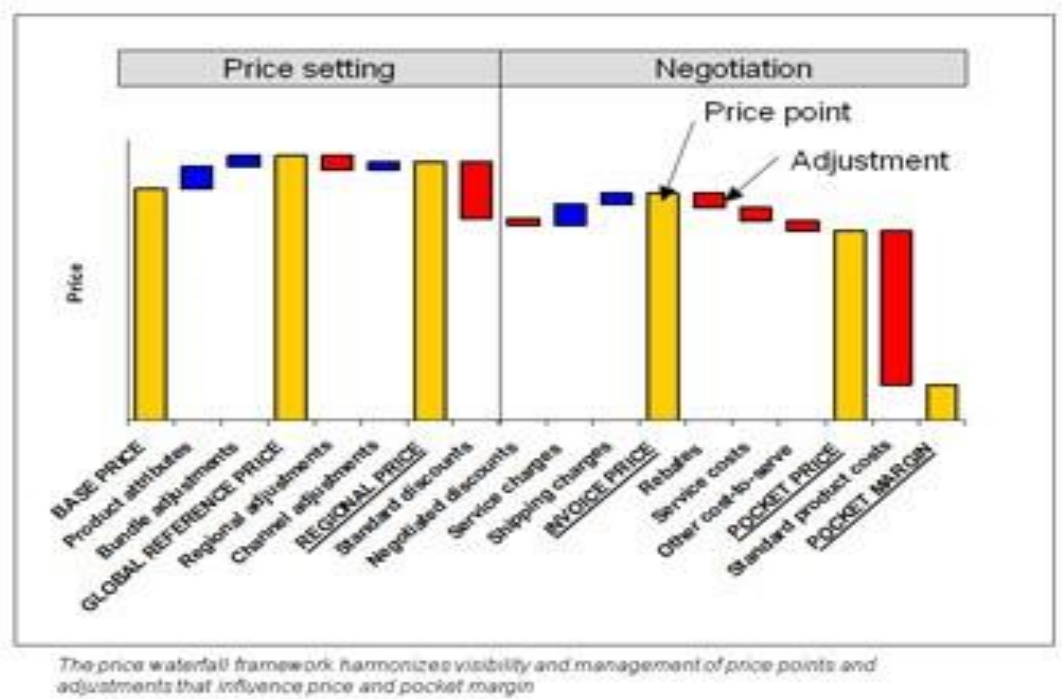

Figure 3. Cascade pricing model - The Price Waterfall model

Source: Own elaboration.

The PWm structure in Fig. 2 is a cascade-like structure. The Base Price is the starting point of the cascade. The cascade elements in Fig. 2 marked yellow are Price Points (PP). These are nodal points of the cascade, i.e. price thresholds. A specific value of a given price threshold is identified in a particular PP.

Adjustments are introduced between particular PPs defined by the master Pricing Policy effective at the time. Adjustments may either be positive (blue in Fig. 3), i.e. increase the PP price threshold value or negative (red in Fig. 3), thus decreasing the PP price threshold value after a given adjustment.

The next Price Points $(\mathrm{k}=1 \ldots \mathrm{n})$ are calculated according to the dependency saying that they sum up the value of the preceding Price Point (k-1) and the Adjustments between particular PPs: PP(k) and PP (k-1). This definition equation is as follows:

Price Point $(k)=$ Price Point $(k-1)+\sum($ Adjustments between PP $)$

The equations meet the criterion of model linearity. The PPs to be defined mandatorily for each PWm model: 
- Base Price - begin, start point

- Invoice Price - the value charged to the customer

- Pocket Price - the gross value

- Pocket Margin - final value, result 'profit or loss'

A PP closing the PWm structure is a PP defined as the Pocket Margin (PM).

A desired condition of a transaction is profitability, i.e. $\mathrm{PM}>0$, for $\mathrm{PM}=0$ or

$\mathrm{PM}<0$ transaction is not profitable.

The chart in the figure is split into two parts:

- Price settings

- Negotiation settings

The Price settings part includes Adjustments linked directly to a company pricing strategy. In such a strategy, a client from a given region is awarded specifically defined discounts or is charged with additional fees. Some examples of adjustments from the Fig 3. include e.g. Product Attribute, Bundle adjustments.

The Negotiation settings part defines a price of a given transaction taking into account all client and product data including adjustments in this part of the WF, i.e. direct transaction parameters - logistic costs and others associated with a transaction. The PWm serves, most of all, to control the Pocket Margin value on an on-going basis when finalising the transaction. All adjustments are defined in the PWm model during negotiations with the client. The discount awarded to the client is solely negotiated. The current profit from the transaction, i.e. a PM value, is determined at each stage of a discussion with a client.

Each transaction has a full set of data and attributes allowing to create a uniform database of all transactions. A formatting process for each transaction in the PWm model enables to use tools for analysing transaction data. The aim of the analysis is to seek such data areas where phenomena occur called a Pricing leakage in the literature. Transactions may happen where $\mathrm{PM}<0$, and where too high discounts are awarded, and where adjustments at a given stage have not been made correctly. Such an on-going transaction analysis allows to find data entered erroneously for discounts, for instance a product was sold in several transactions and the PM values were largely different, the reasons of such a phenomenon should therefore be identified.

The WF cascade structure should be unique for each firm as it reflects its internal structure and the structure of the surrounding market. One can say that a PWm is sort of DNA of a company's costs and its market structure. PWm development is quite a complex process with corporate management being engaged mainly in it and a person with Pricing Analyst profile from a supplier. The more effectively and accurately the process is carried out, the operational result of PWm will be more pronounced.

Fig. 4 shows an example of how can the PWm be defined in practice. Some of the adjustments are hidden, highlighted with grey squares only underneath the cascade chart. 


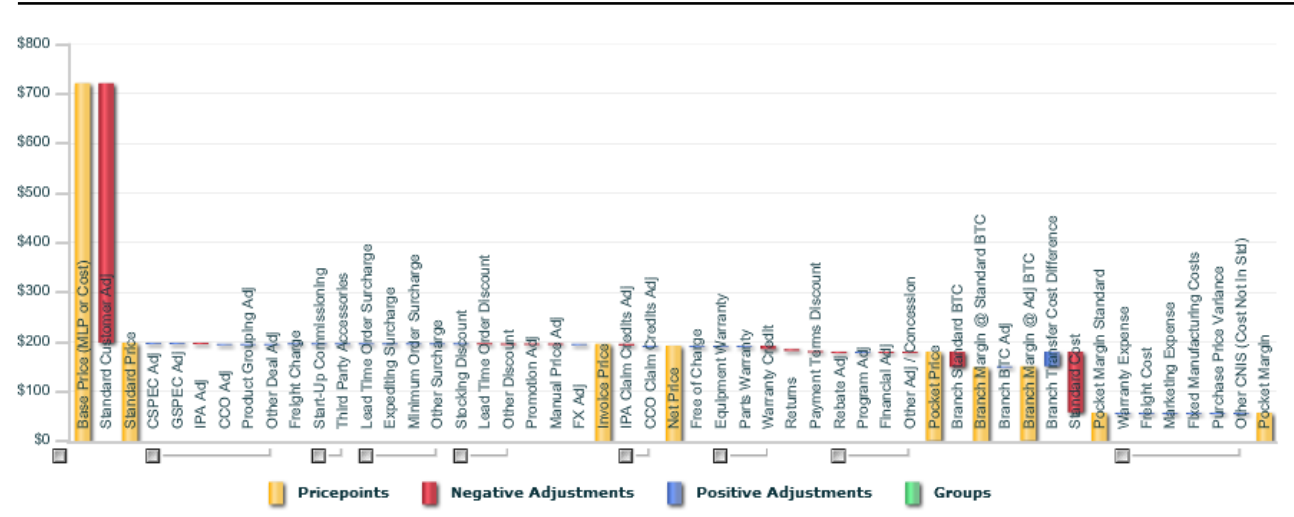

Figure 4. Example of PWm cascade - Vendavo tool

Source: Own elaboration.

The following is possible by introducing the PWm:

- multidimensional transaction data analysis;

- control of cost elements in a given pricing process

- control price leakage, finding the places

- strengthening the costs control and identifying the drivers generating high unit costs

- appraisal of sales and consequences of the conducted pricing strategy

The market position of Innovative Logistic Companies having Logistic information systems can be markedly supported by implementing the PWm model. The results achieved through implementation of such solutions are estimated by profit growth of 2-3 \% of the margin in the first year, McKinsey (http://www.mckinsey.com/insights/marketing_sales/the_power_of_pricing). Such a result is described for companies whose annual transactions account for thousands of records. For those with lower turnover, considerable outcomes should be attained by defining a homogenous cost structure within the company. Price leakage locations should be identified at this stage, i.e. transactions with wrong financial parameters. If transaction data unified with a single PWm model is assembled, this provides an excellent opportunity for creating versatile analyses. This effect, if used appropriately, reinforces a company's market position.

\section{Vendavo's PWm model}

A proposal from Vendavo addressed to SAP system users is an example of such solutions in the field of PWm. This solution is merging the Pricing Strategy and the PWm model combined into a single data flow. An example of exploiting the capabilities of this software package is only presented in this item.Fig. 5 shows one of examples of identifying the places where Profit/Pricing Leakage exists. A classical Tree Map chart is used (https://en.wikipedia.org/wiki/Treemapping). 


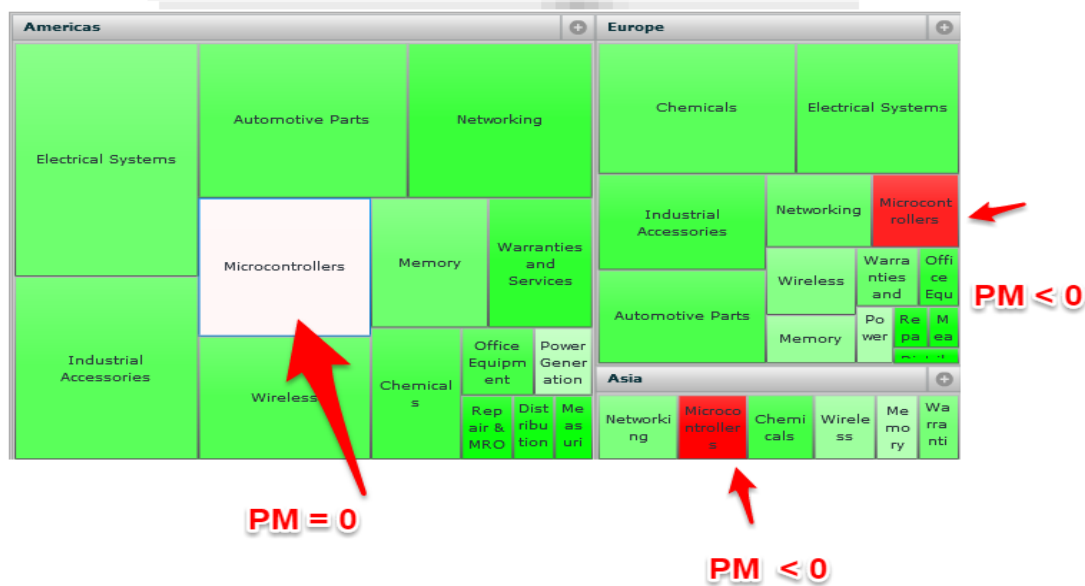

Figure 5. Tree map chart. Vendavo

Source: Own elaboration.

The red areas are the spots generating $\mathrm{PM}<0$ deficit. The successive, more thorough data appraisal with the package of tools should take place now.

Another example of PWm data analysis is in Fig. 6

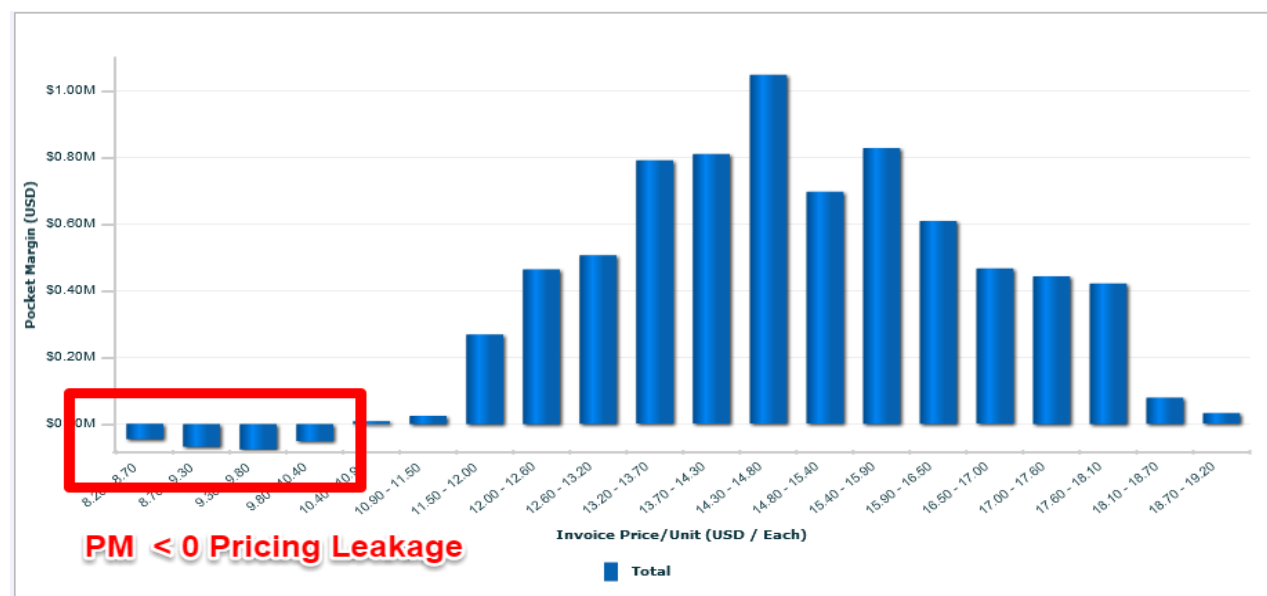

Figure 6. Bar chart with $P M<0$ spots. Vendavo

Source: Own elaboration.

Price ranges are defined for this analysis, over which transactions bring deficits and further analysis of deficit spots should be carried out following this result.

The two charts are only a small sample of capabilities provided by Vendavo's tool. It is beyond the framework of this article to discuss the capabilities of this package. 
Logistic companies should utilise informational data they possess. This offers a possibility of building a better and stronger position in which they can build up their market advantage. Such possibilities can be achieved for instance by introducing a PWm model for setting a product and logistic service price.

\title{
References
}

1. Agent of change, The future of technology distrubtion in business, The Economist, Economist Intelligence Unit, 2012, s. 30-33.

2. Bereza B., Agile Szansa na skokowy wzrost produktywności. Wiedza i Praktyka Warszawa 2014 s.27.

3. Blaik P., Logistyka. PWE Warszawa 2010 p. 377.

4. Bozarth C., Handfield R., Wprowadzenie do zarządzania operacjami i łańcuchem dostaw OnePress/Helion 2007 s. 670-672.

5. Gołembska E., Kompendium wiedzy o logistyce PWN Warszawa 2010 pp. 51-52, 167.

6. http://www.mckinsey.com/insights/marketing_sales/the_power_of_pricing.

7. http://www.mckinsey.com/insights/marketing_sales/the_power_of_pricing.

8. https://en.wikipedia.org/wiki/Treemapping.

9. https://en.wikipedia.org/wiki/Waterfall_model.

10. Jacyna M., Innowacyjna logistyka, Logistyka 5/2011.

11. Kocialski C., Perfect Pricing. ISBN-10:0692313591, 2014.

12. Murphy P., Wood D., Nowoczesna Logistyka Wydanie X Wydawnictwo Helion 2011.

13. Pfohl H.Ch., Innowacyjność w logistyce, tworzenie wartości poprzez innowacje, Polski Kongres Logistyczny Logistics 2008.

14. Skowronek Cz., Sarjusz-Wolski Z., Logistyka w przedsiębiorstwie, PWE, Warszawa 1995

15. Smith G. E., Visionary. Pricing: Reflections and Advances in Honor of Dan Nimer (Advances in Business Marketing and Purchasing) by Gerald E Smith (2012) Emerald Books.

16. Stiving M., Impact Pricing. Entrepreneur Press 2011.

17. Sumorek A., Komunikacja M2M, Logistyka 3/2014.

18. Szkoda M., Realizacja procesów logistyki dystrybucji z zastosowaniem systemu SAP ERP Logistyka 5/2013.

19. Szkoda M., Zastosowanie systemu SAP ERP do obstugi dostaw Just-in-Time oraz Just-inSequence w branży motoryzacyjnej Logistyka 3/2015.

\section{MODELOWANIE CEN W LOGISTYCE PRZY UŻYCIU PRICE WATERFALL MODEL}

\begin{abstract}
Streszczenie: Celem tego artykułu jest zaprezentowanie kaskadowego modelu cenowego - Price Waterfall model do wykorzystania w domenie wiedzy logistycznej. Innowacyjna logistyka powinna się opierać o wykorzystanie w jak największym stopniu możliwości, jakie tworzą technologie informatyczne dostarczające dane do dalszego przetwarzania. W tym wypadku dane generowane prze systemy SAP, CRM mogą zostać użyte do optymalnego modelowania procesu wyznaczania uzasadnionej ekonomicznie ceny. Price Waterfall model został zaproponowany, ponieważ jego struktura odpowiada addytywnej strukturze kosztów logistycznych. Model powinien zebrać informacje dotyczące kosztów z wszystkich możliwych centr kosztów min: marketing, koszty płatności i inne związane ze sprzedażą do klienta. Powinno to stworzyć pełny obraz firmy w domenie kosztów i weryfikować czy dany kontrakt jest korzystny czy też nie.
\end{abstract}

Słowa kluczowe: innowacyjna logistyka, model cenowy, Price Waterfall Analysis, Pricing Process, Pocket Margin, Pricing Leakage 